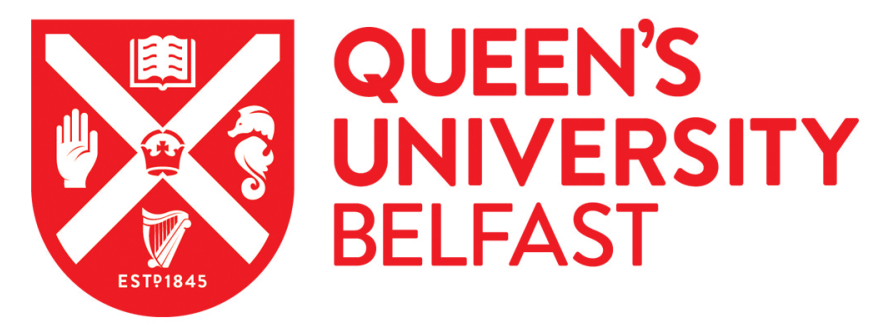

\title{
Frozen Corpses and Feuding Parents: Re JS (Disposal of Body)
}

Conway, H. (2018). Frozen Corpses and Feuding Parents: Re JS (Disposal of Body). Modern Law Review, 81(1), 132-141. https://doi.org/10.1111/1468-2230.12319

\author{
Published in: \\ Modern Law Review
}

Document Version:

Peer reviewed version

Queen's University Belfast - Research Portal:

Link to publication record in Queen's University Belfast Research Portal

Publisher rights

(c) 2018 The Author. The Modern Law Review. This work is made available online in accordance with the publisher's policies. Please refer to any applicable terms of use of the publisher.

\section{General rights}

Copyright for the publications made accessible via the Queen's University Belfast Research Portal is retained by the author(s) and / or other copyright owners and it is a condition of accessing these publications that users recognise and abide by the legal requirements associated with these rights.

Take down policy

The Research Portal is Queen's institutional repository that provides access to Queen's research output. Every effort has been made to ensure that content in the Research Portal does not infringe any person's rights, or applicable UK laws. If you discover content in the Research Portal that you believe breaches copyright or violates any law, please contact openaccess@qub.ac.uk. 


\title{
Frozen Corpses and Feuding Parents: Re JS (Disposal of Body)
}

\author{
Dr Heather Conway*
}

In October 2016, a dying teenager won the legal right to have her remains cryogenically frozen and stored indefinitely in an American clinic. The cryonics aspect was novel, posing questions around the legality of this particular method of corpse 'disposal' in the UK and the processes involved. More significantly, the case raises other substantive legal issues around the fate of the dead- including the status of funeral instructions under English law, and how courts adjudicate parental disputes over the funeral arrangements for a dead child.

\section{Keywords: cryonics, death, families, disputes}

\section{Introduction}

In October 2016, a fourteen-year-old English girl with terminal cancer won the legal right to have her remains cryogenically frozen and stored indefinitely in an American clinic following her death. ${ }^{1}$ While the cryonics aspect was novel and fuelled an intense media interest, ${ }^{2}$ the case raises other important legal issues around the fate of the dead- issues which have much wider implications.

\section{Facts and Outcome}

The teenager (known only in proceedings as 'JS') had been diagnosed with a rare form of cancer in 2015. When active treatment came to an end in August 2016, she began researching cryonics on the internet, in the hope that her body could be frozen on death and reanimated sometime in the future, if a cure became available. ${ }^{3}$ The girl's parents were divorced and on very bad terms with each other; JS lived with her mother, had not had any face-to-face contact with her father since 2008, and was refusing to see him or give him detailed knowledge of her medical condition. Both parents were legally entitled to decide the posthumous fate of their daughter's remains, but were not in agreement. The mother supported her daughter's wish to be cryogenically preserved, and stored

\footnotetext{
* School of Law, Queen's University Belfast and author of The Law and the Dead (Routledge, 2016). Thanks to the anonymous referee for their comments on the original submission.

${ }^{1}$ Re JS (Disposal of Body) [2016] EWHC 2859 (Fam). The judgment had three parts: the first, determining the application and subject to an initial reporting restriction (to avoid any upset to the girl and her family), was handed down orally on 6 October; the second, containing further legal analysis, on 19 October; and the third, dealing with subsequent events, on 6 November.

2 "Terminally III Teen Won Historic Ruling to Freeze Body", BBC News Online (18 November 2016) <http://www.bbc.co.uk/news/health-38012267> (accessed February 2017); "Terminally III Teenager with Rare Form of Cancer Wins Landmark High Court Battle to be Cryogenically Frozen", The Independent (London, 18 November 2016) <http://www.independent.co.uk/news/uk/home-news/cryogenically-frozen-teenagerterminally-ill-cancer-a7424036.html> (accessed February 2017).

3 The scientific and ethical aspects of the process are noted in Pt II.
} 
indefinitely in a specialist facility in Michigan; ${ }^{4}$ the father initially objected (saying he did not want his daughter to 'wake up' in 200 years' time, alone in the United States) but eventually changed his mind- though on condition that he and members of his family could view JS's body after death. However, JS refused, triggering the current application and forcing the court to resolve the parental dispute over what should happen to their daughter's remains.

Peter Jackson J acknowledged that this was a novel application, set against a tragic backdrop of childhood illness and family conflict. Yet "natural sympathy [did] not alter the need for the application to be decided in accordance with established principle, or with principle correctly established". ${ }^{5}$ As regards the financial and logistical issues, the judge noted that the high costs of freezing the body in perpetuity (some $£ 37,000$ for a 'basic' package, around ten times the cost of an average funeral in the UK) ${ }^{6}$ were being met by the girl's maternal grandparents, and that the hospital trust where JS was receiving palliative care was willing to grant a specialist, stand-by cryonics team access to prepare the body within minutes or hours of death. ${ }^{7}$ Turning to the legalities or otherwise of the girl's request, Peter Jackson J accepted that cryonics was not regulated by the Human Tissue Act $2004 ;{ }^{8}$ yet, what JS was proposing here "[did] not seem to be illegal" 9 and her remains could be shipped elsewhere as long as the various legal requirements for doing so were met. ${ }^{10}$ In deciding the dispute between the parents, the judge stated that he "fully under[stood] the father's misgivings"11 around cryopreservation. However, the father's role in his daughter's life had been "extremely limited in recent years", while his request to see JS after her death would "only cause her distress in life". ${ }^{12}$

On these facts, the mother should be allowed to make arrangements for her daughter's body to be preserved. Peter Jackson J granted a specific issue order under $\mathrm{s} 8$ of the

\footnotetext{
${ }^{4}$ The technology is not widely available. Currently, there are only two commercial facilities in America (the Cryonics Institute in Michigan, and the Alcor Life Institute in Arizona), and one in Russia (the KrioRus facility, on the outskirts of Moscow).

${ }^{5}$ [2016] EWHC 2859 (Fam) at [23].

${ }^{6}$ During the various hearings, the girl's father had sought repeated assurances that he would not be liable for the costs of the cryonics process.

${ }^{7}$ Cryonics UK is a voluntary, non-profit organisation of cryonics enthusiasts, which helps those who want this particular option by preparing the body and shipping it (in a preserved state) to a chosen cryonics facilityhttp://www.cryonics-uk.org/ (accessed February 2017). The website describes cryonic preservation as a "sort of 'ambulance to the future'".

8 The 2004 Act has an extensive remit; as well as covering the storage and use of human tissue from living donors, it regulates the removal, storage and use of "relevant material" (defined in s 53) from the dead-including human organs for transplant. However, cryonic preservation is clearly not contemplated under the 2004 Act.

${ }_{9}$ [2016] EWHC 2859 (Fam) at [16].

${ }^{10}$ Namely, the local, state and federal requirements for transporting the remains to the United States, and to the cryonics facility.

11 [2016] EWHC 2859 (Fam) at [38].

12 Ibid.
} 
Children Act 1989, ${ }^{13}$ permitting the mother to implement the necessary steps during JS'S lifetime, as well as an injunction in personam, preventing the father from applying for a grant of administration in respect of his daughter's estate; making or attempting to make arrangements for the disposal of JS's body; and interfering with arrangements made by the mother. ${ }^{14}$

\section{Cryonics- The Legal I ssues}

While freezing isolated human cells and tissue is an established medical procedure ${ }^{15}$ what JS was requesting takes this to a different level. Despite being around since the 1960s, cryonics is still a speculative technology, which uses temperatures of minus $196^{\circ} \mathrm{C}$ to preserve the remains of someone who has been declared legally dead until the underlying cause can be treated, at which point the person can apparently be thawed and reanimated. ${ }^{16}$ The science itself is suspect (cryobiologist $\mathrm{Dr}$ Arthur Rowe likened it to "believing you can turn a hamburger back into a cow"), ${ }^{17}$ and the process raises all sorts of ethical issues around both the treatment of the dead ${ }^{18}$ and highly questionable claims that future revival is possible. ${ }^{19}$

Cryonics is not a lawful method of corpse disposal in some European countries. ${ }^{20}$ In Re JS, this particular question was something of a moot point, given the absence of commercial cryonics facilities in the UK; the court's initial task was to determine whether the teenager's body could have essential procedures performed on it before being transported to Michigan (given the optimal timeframe for the initial freezing process). Peter Jackson J noted that preparing the body within a very short time of death and granting the voluntary cryonics team access to the hospital and use of its facilities raised "serious legal and ethical issues for the hospital trust, which has to act within the law and has duties to its other patients and to its staff". ${ }^{21}$ Conscious of the dying girl's wishes, this particular hospital was prepared to co-operate and, in doing so, to ease her distress; however, the judge emphasised that

\footnotetext{
${ }^{13}$ Which deals with parental responsibility for a child, defined as a person under the age of 18 . Such an order was possible because JS was still alive when it was made- the judge making the point that $\mathrm{s} 8$ does not extend to regulating events after a child's death (ibid at [45] and citing R v Gwynedd County Council, ex p B [1992] 3 All ER 317).

${ }_{14}$ [2016] EWHC 2859 (Fam) at [41]. The judge also made a prospective order under s 116 of the Senior Courts Act 1981- this is discussed below.

${ }^{15}$ Most notably sperm and ova used in fertility treatment and assisted reproduction.

${ }^{16}$ See C Knight, "A Science Without A Deadline" (2008) 19 Engineering and Technology 28. The whole body can be frozen, or just the person's head (the intent being to reconstruct the individual from their brain). While legal death may have occurred, those who opt for cryonics believe that physical death has not occurred and that the body is simply being placed in a state of long-term suspension until revived and brought back to life.

17 Quoted in "Frozen Future", National Review, 9 July 2002.

${ }^{18}$ In the present case, concerns were expressed about the procedures performed on the teenager's body after death, and the manner in which these were carried out by the cryonics team. These are discussed below.

${ }^{19}$ See D Shaw, "Cryoethics: Seeking Life After Death" (2009) 23 Bioethics 515 and N Bhatia and J Savulescu, "Cryonics: Hype, Hope or Hell", The Conversation, 23 November 2016.

${ }^{20}$ For example, in France which only permits burial, cremation or donation to medical science.

${ }^{21}$ [2016] EWHC 2859 (Fam) at [12].
} 
a different hospital or medical facility might not be so accommodating, and that this decision did "not set a precedent for other cases". ${ }^{22}$ And the ruling on cryonics was equally restrictive:

I cannot emphasise enough what this case is not about. It is not about whether cryonic preservation has any scientific basis or whether it is right or wrong. The court is not approving or encouraging cryonics, still less ordering that JS's body should be cryonically preserved. ${ }^{23}$

The judge's misgivings are clear, and are brought into sharper focus at the end of his judgment when drawing attention to events which occurred on the day of JS's death. Cryonic preservation was completed, despite the voluntary team being "under-equipped and disorganised", and the way in which the process was handled causing "real concern to the [hospital's] medical and mortuary staff". ${ }^{24}$ Meanwhile, the mother's preoccupation with the post-mortem arrangements was "at the expense of being fully available to J S"25 on her daughter's last day- a somewhat paradoxical outcome, given that the father's initial objections were based on the thought of his daughter 'waking up' alone and frightened in another country, years from now, yet JS's demise might also have been lonelier and more frightening than it would have been if her mother had been there to comfort and support JS fully throughout. Of course, these events could not have been anticipated; but they reinforce the sense of not setting a precedent here and treating future applications with caution.

Looking beyond the facts of this particular case, cryonics would raise all sorts of legal issues if commercial facilities were ever opened in the UK- not to mention the legal quagmire that would have to be negotiated if reanimation ever traversed the realms of science fiction to become a practical reality. ${ }^{26}$ Peter Jackson J in Re JS suggested a need for "proper regulation of cryonic preservation in the country if it is to happen in the future"27- though one might argue that bringing the procedure within the remit of the Human Tissue Act $2004^{28}$ is not the best solution, because of the uniquely complex and legally distinctive issues posed by cryonics. Given the small number of people who opt for the procedure each year (cost is a major factor, alongside what are currently unsubstantiated claims about being able to return from the dead), this is not such an

\footnotetext{
22 Ibid at [28].

23 Ibid at [30] (emphasis in original).

${ }^{24}$ Ibid at [68].

25 Ibid.

${ }^{26}$ Some of these issues are explored in H Conway, "Is Someone Reanimated From Cryogenic Freezing Legally Dead or Alive? And Other Problems", The Conversation, 30 November 2016 at https://theconversation.com/issomeone-reanimated-from-cryogenic-freezing-legally-dead-or-alive-and-other-problems-69514 (last accessed 5 December 2017).

27 [2016] EWHC 2859 (Fam) at [69].

28 Mooted by Peter Jackson J, earlier in his judgment- ibid at [15].
} 
urgent task- despite all the publicity surrounding this particular case. In the meantime there are more pressing issues around corpse disposal. While cremation and burial still dominate, other methods are being developed: resomation (a liquefaction process which uses alkaline hydrolysis to dissolve the body's organic matter) and promession (here, liquid nitrogen super-cools the body before the brittle remains are shattered using ultrasonic vibration). ${ }^{29}$ Shaped by environmental concerns, these alternatives to burial and cremation are more likely to be commercially viable in the shorter term, ${ }^{30}$ and will require discrete regulatory frameworks.

\section{Funeral Instructions-Personal Preference, Not Presumptive Right}

One of the key aspects of Re JS was the girl's alleged right to choose what happened to her body when she died. Cryonic preservation is undoubtedly an esoteric request; yet many people have specific views on their post-mortem fate- for example, whether they should be buried or cremated, the type of funeral ceremony, and where they want their remains or post-cremation ashes to be placed. Personal preference is a factor here, as are specific religious and cultural beliefs. However, as the law currently stands throughout the UK, an individual has no legal right to determine their own funeral arrangements.

This particular anomaly stems from the nineteenth century case of Williams $v$ Williams ${ }^{31}$ which decided that, since a dead body does not constitute property, it cannot be bequeathed by will. ${ }^{32}$ Instead, decision-making powers fall on the executor where the deceased made a will; ${ }^{33}$ for intestate deaths, the highest ranked next-of-kin for estate administration purposes has the final say, defined ${ }^{34}$ as the deceased's surviving spouse or civil partner, followed by children, then parents and siblings in descending order. ${ }^{35}$ Peter Jackson J in Re JS highlighted the common law rule in Williams, and reiterated the fact that "in English law, there is no right to dictate the treatment of one's body after death" and that this is the position "regardless of testamentary capacity or religion". ${ }^{36}$ While JS's wishes were "relevant, perhaps highly so" they were "not determinative". ${ }^{37}$ Likewise, the court's role was "not to give directions for the disposal of the body"; 38 its only function

\footnotetext{
${ }^{29}$ For an overview of both methods and the legal issues surrounding them, see H Conway, The Law and the Dead (Routledge, 2016), pp 47-50 and the various sources cited there.

${ }^{30}$ Assuming that they are also viewed as socially acceptable alternatives!

31 (1882) 20 Ch D 659.

32 Though the underlying rationale is questionable, given that older authorities were misinterpreted and clearly stated that corpses could not own property (as opposed to corpses not being property). For an excellent critique, see P Matthews, "Whose Body? People as Property" (1983) 36 Current Legal Problems 193, pp 196-221.

33 See Grandison v Nembhard [1989] 4 BMLR 140.

34 In England and Wales, under s 46 of the Administration of Estates Act 1925 (as amended).

35 See Dobson v North Tyneside Area Health Authority [1996] 4 All ER 474.

${ }^{36}$ [2016] EWHC 2859 (Fam) at [48].

37 l bid.

$38 \mathrm{Ibid}$ at [49]. The same point has been stressed elsewhere- see for example, the comments of Patten J in Scotching v Birch [2008] EWHC 844 (Ch) at [7] ("The court has no power to direct what form anybody's funeral
} 
was to resolve the parental disagreement by deciding who was entitled to make the funeral arrangements, and preference was given to the mother here.

So, the fact that JS's funeral instructions were not legally binding had nothing to do with her being a minor: the position would have been the same if she had been an adult (though the dispute would probably not have ended up in court, because JS would have been able to make a will, appointing her mother as executor on the basis that the mother would comply with her wishes). ${ }^{39}$ The impact of the deceased's own funeral preferences has been raised in a number of recent English cases, with some courts viewing them as an important reference point when resolving family disputes of this nature- even if not legally binding. ${ }^{40}$ However, Cranston J went further in Burrows v HM Coroner for Preston, ${ }^{41}$ when discussing the impact of the European Convention on Human Rights on the common law position:

One thing is clear, that in as much as our domestic law says that the views of a deceased person can be ignored it is no longer good law...t is quite clear from the jurisprudence of the European Courts [sic.] of Human Rights that the views of a deceased person as to funeral arrangements and the disposal of his or her body must be taken into account. ${ }^{42}$

Despite such a strong statement, the fact remains that funeral instructions are inoperative under English law, and can simply be ignored by those who are entitled to make the final dispositive arrangements. This has been severely criticised, ${ }^{43}$ with public expectations, contemporary values, and respect for personal autonomy all strengthening the case for abandoning the rule in Williams. On a positive note, the issue may be revisited in the near future: the Law Commission for England and Wales has identified burial and cremation as a potential law reform area, and questioned whether an individual's wishes concerning the disposal of their body should be legally binding, ${ }^{44}$ while a recent Private Member's Bill

should take"). However, see In the Matter of Ian Stewart-Brady (Deceased) [2017] EWHC 2543 (Ch) where specific directions were given about the cremation arrangements for 'Moors Murderer' Ian Brady.

${ }^{39}$ Something which Peter Jackson J highlighted in his judgment- [2016] EWHC 2859 (Fam) at [25].

${ }^{40}$ See for example, Hartshorne v Gardner [2008] EWHC B3 (Ch) at [7] (the deceased's wishes are "one of the relevant factors to be taken into consideration") and Anstey v Mundle [2016] EWHC 1073 (Ch) at [45] (the deceased's desire to be buried in his native Jamaica was "a particularly weighty factor").

${ }^{41}$ [2008] EWHC 1387 (Admin).

42 Ibid at [20], citing X v Federal Republic of Germany (1981) 24 D \& R 137 and Dödsbo v Sweden (2007) 45 EHRR 22. The rights enshrined in Articles 8 and 9 of the Convention in particular (the right to private and family life; the right to freedom of religion) could support the case for allowing an individual to dictate the posthumous fate of their remains- see the discussion in Conway ( $n$ 29), pp 139-144. However, Cranston J's comments were criticised in Ibuna v Arroyo [2012] EWHC 428 (Ch) at [50] where Peter Smith J questioned the "post-mortem application of human rights in relation to a body". And while personal representatives ought to take account of D's wishes, these "should not...have the paramountcy" suggested in Burrows- ibid at [55].

43 See RN Nwabueze, "Legal Control of Burial Rights" (2013) 2 Cambridge Journal of International and Comparative Law 196 and Conway (n 29), ch 5.

${ }^{44}$ The consultation opened in the autumn of 2016. It is unclear what projects the Law Commission will pursue as part of its thirteenth programme of law reform (2017-2020). 
before the Westminster Parliament is proposing changes to this effect. ${ }^{45}$ It is also worth pointing out that the legal position is very different elsewhere. For example, a number of US states have 'mortal remains statutes' which allow an individual to determine the posthumous disposal of their remains, ${ }^{46}$ while s 6 of the Cremation, Interment and Funeral Services Act 2004 Act in the Canadian province of British Columbia also gives legal weight to the deceased's funeral preferences. ${ }^{47}$

\section{Funeral Disputes Between Feuding Parents: Who Has the Final Say?}

Families clashing over a dead relative's funeral arrangements occurs more often than we might think, and English courts have encountered these disputes on numerous occasions. ${ }^{48}$ The legal position is fairly straightforward, because the executor or presumptive estate administrator has the final say. However, intestate deaths create problems where two or more people fall within the same kinship tier and have equal rights but different views on what should happen to the deceased's remains. There is no mechanism for ranking the competing claims here- and a classic example involves separated parents (who may have re-partnered) fighting over the remains of a dead child, often where the child is a minor but also where an adult child dies without legally closer kin. ${ }^{49}$

Despite all the focus on cryonics, this was the crux of the issue in Re JS: whether the mother or the father should determine their daughter's post-mortem fate. In favouring the mother and making a specific issue order under s 8 of the Children Act 1989, Peter Jackson J was influenced by "JS's wishes and her acute emotional needs", 50 and the fact that the mother (who had a much stronger relationship with her daughter) was prepared to carry out her wishes. The fact that both parents were entitled to a grant of administration over their child's estate ${ }^{51}$ and, therefore, had equal rights to arrange the disposal of her body, could be dealt with under s 116 of the Senior Courts Act 1981 which gives the High Court discretionary powers to displace the administrator of an estate if

\footnotetext{
45 Burial Rights Reform Bill 2016-17, and introduced in January 2017 by The Hon David Burrows MP- see http://services.parliament.uk/bills/2016-17/burialrightsreform.html (accessed February 2017). The Bill's progress was halted when Parliament was dissolved for the June 2017 General Election.

${ }^{46}$ See the discussion in Conway (n 29), pp 133-134.

47 Similar changes are being proposed in the Australian state of Victoria- see Victorian Law Reform Commission, Funeral and Burial Instructions: Report (December 2016).

${ }^{48}$ Examples include Grandison v Nembhard [1989] 4 BMLR 140; Buchanan v Milton [1999] 2 FLR 844; Fessi v Whitmore [1999] 1 FLR 767; Hartshorne v Gardner [2008] EWHC B3 (Ch); Scotching v Birch [2008] EWHC 844 (Ch); Burrows v HM Coroner for Preston [2008] 2 FLR 1225; and Anstey v Mundle [2016] EWHC 1073.

49 In other words, where an adult child dies without leaving a spouse or civil partner, or a child of his/her own. The other obvious scenario involves siblings fighting over a dead parent (or over the funeral arrangements for another sibling who died without legally closer kin- for example, if the deceased had no spouse or civil partner, and no children or surviving parents).

${ }^{50}$ [2016] EWHC 2859 (Fam) at [46].

51 Non-Contentious Probate Rules 1987, r 22(1)(c).
} 
"special circumstances" exist. ${ }^{52}$ Here, both the "nature of the family breakdown and of J S's wishes"53 qualified as special circumstances, leading Peter Jackson J to grant a prospective order $^{54}$ substituting the mother as sole estate administrator, in place of the mother and father jointly.

Such cases are always difficult, and faced with previous parental disputes over a dead child, English courts have reached different conclusions. ${ }^{55}$ Circumstances vary, and any decision will always be fact-sensitive. The outcome in Re JS seems instinctively correct, given the family history, the well-documented tensions between father and daughter, and the mother's willingness to do what JS wanted. However, courts elsewhere might have reached a very different conclusion. For example, several Canadian provinces ${ }^{56}$ have a statutory rule which favours the elder of the deceased's two parents in these circumstances- a blunt legal solution which may be effective, but is totally arbitrary and ignores the complex factual and emotional nuances of a particular dispute. ${ }^{57}$

\section{Deciding the Fate of the (Un) Dead}

Part of the judgment in Re JS focused on whether the court should actually make a prospective order under $\mathrm{s} 116,{ }^{58}$ since the girl was still alive and most funeral disputes are litigated after death.

A similar issue arose in the New Zealand case of Re JSB (A Child), 59 where a five-year-old boy (left severely brain damaged by previous injuries inflicted by his mother) was likely to die within days or weeks. The boy's parents ${ }^{60}$ and his paternal grandmother disagreed over where his ashes would be interred, and advance directions were sought from the High Court. Heath J decided that the court had jurisdiction to make such an order, but declined

\footnotetext{
${ }^{52}$ Although more commonly concerned with estate management, disposal of the dead also falls within the ambit of s 116 and the provision has been invoked in several cases- see Buchanan v Milton [1999] 2 FLR 844, Burrows v HM Coroner for Preston [2008] EWHC 1387 (Admin) and I buna v Arroyo [2012] EWHC 428 (Ch). Peter Jackson $J$ in Re JS also suggested that the issue could be dealt with under the court's inherent jurisdiction- echoing comments in Anstey v Mundle [2016] EWHC 1073.

53 [2016] EWHC (Fam) 2859 at [54].

54 See Pt V.

${ }^{55}$ For example, in both Fessi v Whitmore [1999] 1 FLR 767 and Hartshorne v Gardner [2008] EWHC B3 (Ch)) the emotional and geographical ties to the proposed burial site were important (though in the latter case the court was also swayed by the majority views of deceased's father, fiancée and brother on one side of the dispute, compared with the deceased's mother on the other side).

${ }^{56}$ Namely, British Columbia, Alberta and Saskatchewan- see respectively s 5(3) of the Cremation, Interment and Funeral Services Act 2004 (BC); s 36(3) of the General Regulation (Funeral Services Act) Alta Reg 226/98 and ss 11(2)-(3) of the General Regulation (Cemeteries Act) Alta Reg 249/1998; and s 91(2)(b) of the Funeral Services Act 1999 (Sask).

57 At the other end of the legislative spectrum, the US state of Pennsylvania (see 20 PA. CONST. STAT. ANN. 305(d)(2)) favours the person who was "closest" to the deceased in life- a factor which Peter Jackson J was undoubtedly influenced by in Re JS.

58 Or under its inherent jurisdiction- see $\mathrm{n} 52$.

59 [2009] NZHC 2054.

60 Who were still together; the mother had been released on parole by the time of the hearing.
} 
on the basis that it would be premature: circumstances could change (the parents and paternal grandmother might reconcile), and predetermining the child's funeral arrangements would not be appropriate. ${ }^{61}$

Peter Jackson J noted this decision in Re JS, but reached a different conclusion. There was no time for revisiting the issue after death here (cryonics requires immediate action), and the issues facing the court were both pressing and real:

There is ample authority for the proposition that the court should not stray into deciding hypothetical questions.... That is not the position here: this is an actual problem that needs to be resolved now, albeit the resolution will play out at a future date. ${ }^{62}$

The arguments for and against making a prospective order were listed earlier in the judgment: all parties were now represented before the court, resolving the issue should "prevent undignified scenes later"63 and clarity would help third parties know how they should act; but a later change of circumstances would undermine the decision and "as a matter of public policy [courts] may not wish to encourage similar applications". 64 In rejecting the opposing claims, the judge emphasised that things were unlikely to change before JS died (the family breakdown was "very deep and long-standing") and that courts "could not decline to deal with a situation that demands resolution" because of public policy concerns. ${ }^{65}$

So, where death is imminent ${ }^{66}$ and families are already fighting over the arrangements and reconciliation (or compromise) is unlikely, a prospective ruling may be possible. ${ }^{67}$ The number of situations in which this actually occurs is likely to be small- and it is worth pointing out that the girl's own wishes were also an important part of the factual matrix in Re JS, even if they were not legally binding. At a basic human level, it seems distasteful for families to be disputing the fate of someone who is not yet dead, and most legal systems would not want to encourage this, though Peter Jackson J stressed that if predeath applications "were wrongly bought, they could be dealt with accordingly". ${ }^{68}$

\footnotetext{
${ }^{61}$ Note also the decision of the Northern Ireland High Court in Re LL [2005] NIQB 83 where Deeny J ruled that the foster parents of an eleven-year-old boy who was dying from cancer could decide his funeral arrangements, despite objections from the mother. The merits of a prospective order were not questioned.

62 [2016] 2859 (Fam) at [56].

63 I bid at [36].

${ }^{64} \mathrm{Ibid}$ at [35].

65 Ibid at [37].

${ }^{66}$ The fact that the individual might die at some future point would not suffice.

${ }^{67}$ Although all the cases mentioned here involve children, it is not difficult to imagine similar situations involving adults who are close to death yet incapacitated in some way- for example, where someone is on life-support, has suffered brain damage in a serious accident or has a severe mentally disability, and that person's family are already at loggerheads.

68 [2016] 2859 (Fam) at [37].
} 


\section{Conclusion}

As far as the cryonics issue was concerned, Re JS was a paradigmatic case: the teenager had made her wish to be preserved in perpetuity clear; the funds were available; her mother was prepared to carry out JS's wishes; and the hospital was willing to facilitate access for the stand-by cryonics team. However, the ruling must be looked at in this particular context, and does not set a clear precedent for similar disputes, should they arise. The logistical and practical issues would probably be similar, but the court's proverbial hands would be tied if another hospital trust or medical facility was unwilling to co-operate or surviving relatives refused to honour the dying person's request (or simply could not afford the costs of the procedure). ${ }^{69}$

Beyond cryonics, the decision in Re JS raises more substantive legal issues around the fate of human remains. Family funeral disputes will continue to be a sad yet fertile source of litigation, and where separated parents are fighting over the remains of a dead child, courts will still have to search for specific ways of ending the impasse and favouring one parent over another- something which is much more difficult where both had close and enduring emotional relationships with their child, unlike the unfortunate situation in the present case. The question of prospective rulings may arise again, given the court's willingness to issue one in Re JS; and while fully merited on the facts, it will be interesting to see how future cases are determined and how any unwarranted applications are dispensed with. Finally, there is the issue of whether an individual's funeral instructions should be legally binding, something which was also brought into sharp focus in the present case and will continue to be a source of debate. If the Law Commission decides to look at this area in the future, the deceased's own preferences could become the primary reference point in funeral disputes. Courts would give effect to them by granting custody of the corpse or post-cremation ashes to the relative or individual who was intent on doing what the deceased wanted.

${ }^{69}$ Assuming there were insufficient funds in the deceased's estate to cover these costs. 
